\title{
SYNTHESIS AND CRYSTAL CHEMISTRY OF SOME DOUBLE CHAIN SILICATES
}

\author{
R.P. GUNAWARDANE \\ Department of Chemistry, University of Peradeniya, Peradeniya.
}

(Received : 05 January 1994; accepted : 23 June 1994)

\begin{abstract}
Synthesis and crystal chemistry of silicates containing double chain anions with some $\mathrm{M}^{3 *}$ cations ( $\mathrm{Fe}, \mathrm{Sc}, \mathrm{Y}, \mathrm{In}, \mathrm{Gd}$ ) and $\mathrm{M}^{*}$ cations $(\mathrm{Zr}, \mathrm{Ti}, \mathrm{Sn}, \mathrm{Hf}$ ) have been investigated. The phases have been synthesized either by direct solid state reaction or by crystalization of glass. X-ray powder patterns indicate that they are isostructural with the minerals Zektzerite, $\mathrm{NaLiZrSi}_{8} \mathrm{O}_{18}$, and emeleusite, $\mathrm{Na}_{2} \mathrm{LiFeSi}_{6} \mathrm{O}_{15}$, found in nature. They all possess double chain silicate anion with 6-tetrahedra unit, $\left[\mathrm{Si}_{6} \mathrm{O}_{15}{ }^{6}\right]$, referred to as Sechser Doppelkette. This family of silicates are highly resistant to chemical attack and exhibit high thermal stability. It is apparent that the double chain configuration with characteristic 6-tetrahedra repeat unit is found in a family of isostructural phases which are very tolerant for a wide range of cationic substitutions. This unusual tolerance of cations of varying size can be attributed to the presence of a flexible octahedraltetrahedral chain in the structure. Introduction of progressively larger cations expands the $\mathrm{MO}_{6}$ octahedra, but much of the expansion is taken up by the compression of $\mathrm{LiO}_{4}$ tetrahedra. Thus, it is possible that many more such phases could occur in nature as minerals.
\end{abstract}

Key Words: Crystal sructure, Double-chain silicates.

\section{INTRODUCTION}

Although naturally occurring silicates containing infinite double chains (e.g. amphiboles) have long been known, it has only recently become apparent that a number of anhydrous silicates containing double-chain anions exist.

$\mathrm{Na}_{2} \mathrm{Mg}_{2} \mathrm{Si}_{6} \mathrm{O}_{15}$ has been reported ${ }^{1}$ in a study of phase equilibria in the system $\mathrm{Na}_{2} \mathrm{O}-\mathrm{MgO}-\mathrm{SiO}_{2}$. Crystal structure analysis ${ }^{2}$ of $\mathrm{Na}_{2} \mathrm{Mg}_{2} \mathrm{Si}_{6} \mathrm{O}_{16}$ showed that it contained a new type of double-chain silicate anion having characteristic repeat of six tetrahedra $\left(\sim 10.3^{\circ} \mathrm{A}\right)$. Liebau ${ }^{3}$ described this anion as "Sechser Doppelkette" unit. Another compound containing the same anion unit, $\mathrm{Na}_{2} \mathrm{LiFeSi}_{6} \mathrm{O}_{16}$, had been synthesized ${ }^{4}$ and structure determined. Subsequently, a new zirconium containing mineral, zektzerite, ${ }^{5} \mathrm{NaLiZrSi}_{8} \mathrm{O}_{15}$, had been discuvered and its structure determined. In fact, it is apparent that these three phases- $\mathrm{Na}_{2} \mathrm{Mg}_{2} \mathrm{Si}_{8} \mathrm{O}_{15}$, $\mathrm{Na}_{2} \mathrm{LiFeSi}_{6} \mathrm{O}_{15}$, and $\mathrm{NaLiZrSi} \mathrm{O}_{6} \mathrm{O}_{15}$ are isostructural. Moreover, $\mathrm{Na}_{2} \mathrm{LiFeSi}_{6} \mathrm{O}_{16}$ has been found to occur in nature as emeleusite. ${ }^{\circ}$

The range of isomorphic substitutions in this group is clearly exceptional amongst silicates. Cations with widely different sizes and varying charges are 
apparently capable of occupying equivalent sites in the structure. These substitutions are shown below:

$$
\begin{array}{ll}
\mathrm{M}^{2+}: \text { Synthetic } & \mathrm{Na}_{2} \mathrm{Mg}_{2} \mathrm{Si}_{6} \mathrm{O}_{15} \\
\mathrm{M}^{3+}: \text { Synthetic } & \mathrm{Na}_{2} \mathrm{LiFeSi}_{6} \mathrm{O}_{15} \\
\text { Mineral Emeleusite } & \mathrm{Na}_{2} \mathrm{LiFeSi}_{6} \mathrm{O}_{15} \\
\mathrm{M}^{4+} \text { : Mineral Zektzerite } \mathrm{NaLiZrSi}_{6} \mathrm{O}_{15}
\end{array}
$$

Four cations $(2 \mathrm{Na}+2 \mathrm{Mg})$ are required to balance the charge on the silicate anion in $\mathrm{Na}_{2} \mathrm{Mg}_{2} \mathrm{Si}_{6} \mathrm{O}_{16}$ where as only three $(1 \mathrm{Li}+1 \mathrm{Na}+1 \mathrm{Zr})$ are required in zektzerite. Thus, the structure is tolerant of cation vacancies.

In the present study, synthesis and crystal chemistry of six new phases in the emeleusite family (with +1 and +3 cations) and three new phases in the zektzerite family (with +1 and +4 cations) have been investigated.

\section{METHODS AND MATERIALS}

Synthesis: ANALAR grade sodium carbonate, lithium carbonate, crushed quartz $\left(\mathrm{SiO}_{2}\right) ; \mathrm{M}(\mathrm{III})$ and $\mathrm{M}$ (IV) oxides or carbonates (reagent grade) were used as starting materials. The batches were mixed in an agate mortar under acetone or alcohol, dried, placed in a platinum crucible and sintered at appropriate temperature. The firing temperature was carefully selected in order to avoid partial melting and to obtain a maximum yield of pure phases. In some cases, sintering for prolonged periods $(5-10 \mathrm{~d})$ with intermediate crushing failed to give complete reaction. In such cases, the compositions were melted, quenched to a glass and finally crystallized the glass at temperatures $20-50^{\circ} \mathrm{C}$ below the estimated solidus temperature. In most cases this procedure yielded homogeneous products. It was necessary to carry out firing, quenching and crushing several times in order to obtain a homogeneous product.

Characterization of Phases: After crystallization of glass or the preparation of sintered product, the crystalline phases present were identified by powder X-ray diffraction using a Hagg Guinier camera with $\mathrm{Cu} \mathrm{K} \alpha$ radiation. The powder $\mathrm{X}$ ray films were taken with $\mathrm{KCl}$ as an internal standard. Presence of melt or glass was detected by petrographic examination with a polarizing microscope.

Single crystals of the phases were grown at temperatures just below melting points and the unit cell contents and space groups were confirmed directly from rotation, Weissenberg and precission photographs.

Thermal Behaviour: Melting points were determined by using a quenching furnace and employing the static equilibration method. Two types of charges were used: glass and glass previously crystallized and completely converted to a crystalline phase. The samples were contained in platinum foil envelopes and 
were held at a constant temperature for $12-24 \mathrm{~h}$. The sample was then quenched to ambient temperatures and the phases present determined. Furnace temperature was measured with a $\mathrm{Pt}-13 \% \mathrm{Rh}$ thermocouple which was calibrated against the melting point of gold.

\section{RESULTS}

The following members of the Emeleusite family, $\mathrm{LiNa}_{2} \mathrm{M}^{\mathrm{m}} \mathrm{Si}_{6} \mathrm{O}_{15}$, have been synthesized.

$\mathrm{Na}_{2} \mathrm{LiFeSi}_{6} \mathrm{O}_{15}$ - synthetic emeleusite

$\mathrm{Na}_{2} \mathrm{LiMnSi}_{6} \mathrm{O}_{15}$

$\mathrm{Na}_{2} \mathrm{LiCrSi}_{6} \mathrm{O}_{15}$

$\mathrm{Na}_{2} \mathrm{LiScSi}_{6} \mathrm{O}_{15}$

$\mathrm{Na}_{2} \mathrm{LiYSi}_{6} \mathrm{O}_{15}$

$\mathrm{Na}_{2} \mathrm{LiInSi}_{6} \mathrm{O}_{15}$

$\mathrm{Na}_{2} \mathrm{LiGdSi}_{6} \mathrm{O}_{15}$

Similarly, the following compounds in the zektzerite family, $\mathrm{NaLiM}^{\mathrm{iv}} \mathrm{Si}_{8} \mathrm{O}_{18}$, have been successfully synthesized.

$\mathrm{NaLiZrSi} \mathrm{O}_{15}$ - synthetic zektzerite

$\mathrm{NaLiTiSi}_{6} \mathrm{O}_{15}$

$\mathrm{NaLiSnSi}_{6} \mathrm{O}_{15}$

$\mathrm{NaLiHfSi}_{6} \mathrm{O}_{15}$

The charge balance in the $\mathrm{Si}_{6} \mathrm{O}_{15}{ }^{8}$ anion may be achieved by any one of the following cation combinations.
(1) $2 \mathrm{M}^{1+}+2 \mathrm{M}^{2+}$
e.g. $\mathrm{Na}_{2} \mathrm{Mg}_{2} \mathrm{Si}_{6} \mathrm{O}_{15}$
(2) $3 \mathrm{M}^{1+}+\mathrm{M}^{3+}$
e.g. emeleusite family
(3) $2 \mathrm{M}^{1+}+\mathrm{M}^{4+}$
e.g. zektzerite family

Powder X-ray patterns of synthetic Fe, Cr, Mn, Sc, Y, In and Gd members of the emeleusite family are very similar to the reported ${ }^{6}$ powder pattern of the mineral emeleusite. However, substitution of a heavier and somewhat larger $\mathbf{M}^{3+}$ ion changes the axial ratios and alter the intensities of individual reflections gradually.

Microscopically these phases appear as lath or platy crystals having low birefringence. The unit cell dimensions estimated using rotation and Weissenberg photographs of $\mathrm{Zr}, \mathrm{Sn}$ and $\mathrm{Ti}$ zektzerite are shown in Table 1. Isostructural nature is evident from their similarity of unit cell dimensions. 
Table 1: Cell dimensions of some double chain silicates

\begin{tabular}{lccrc}
\hline Compound & a & $\underline{b}$ & \multicolumn{1}{c}{$\left({ }^{\circ} \mathrm{A}\right)$} & $\mathrm{V}\left({ }^{0} \mathrm{~A}^{3}\right)$ \\
\hline $\mathrm{LiNaZrSi}_{6} \mathrm{O}_{15}$ & $14.332(1)$ & $17.350(1)$ & $10.165(1)$ & 2528 \\
$\mathrm{LiNaSnSi}_{6} \mathrm{O}_{15}$ & $14.296(1)$ & $17.171(2)$ & $10.044(1)$ & 2466 \\
$\mathrm{LiNaTiSi}_{\mathrm{g}} \mathrm{O}_{15}$ & $14.233(3)$ & $17.064(3)$ & $9.932(1)$ & 2412 \\
\hline
\end{tabular}

Melting behaviour of the synthetic double-chain silicates investigated in the present study is shown in Table 2. All members of the zektzerite family are incongruently melting while congruent as well as incongruent melting points are observed for the emeleusite family.

Table 2: Melting behaviour of the synthetic phases

\begin{tabular}{|c|c|c|c|}
\hline Phase & Melting & $\operatorname{oint}\left({ }^{\circ} \mathrm{C}\right)$ & Nature of Melting \\
\hline $\mathrm{LiNaZrSi}_{8} \mathrm{O}_{16}$ & 1162 & +4 & Incongruent \\
\hline LiNaTiSi $_{8} \mathrm{O}_{15}$ & 923 & +5 & Incongruent \\
\hline $\mathrm{LiNaSnSi}_{8} \mathrm{O}_{.15}$ & 1124 & +4 & Incongruent \\
\hline $\mathrm{LiNaHfSi}_{6} \mathrm{O}_{15}$ & 1250 & +5 & Incongruent \\
\hline $\mathrm{LiNa}_{2} \mathrm{FeSi}_{8} \mathrm{O}_{16}$ & 965 & +5 & Incongruent \\
\hline $\mathrm{LiNa}_{2} \mathrm{ScSi}_{8} \mathrm{O}_{15}$ & 1230 & +3 & congruent \\
\hline $\mathrm{LiNa}_{2} \mathrm{YSi}_{6} \mathrm{O}_{16}$ & 120 & +3 & congruent. \\
\hline $\mathrm{LiNa}_{2} \mathrm{InSi}_{6} \mathrm{O}_{18}$ & 1086 & +5 & congruent \\
\hline $\mathrm{LiNa}_{2} \mathrm{GdSi}_{6} \mathrm{O}_{15}$ & 985 & +5 & Incongruent \\
\hline
\end{tabular}

\section{DISCUSSION}

The charge balance in the $\mathrm{Si}_{6} \mathrm{O}_{18}{ }^{8}$ anion may be achieved by any one of the following cation combinations.
(1) $2 M^{1+}+2 M^{2+}$
(2) $3 M^{1+}+M^{3 *}$
e.g. $\mathrm{Na}_{2} \mathrm{Mg}_{2} \mathrm{Si}_{8} \mathrm{O}_{15}$
(3) $2 M^{1+}+M^{4+}$
e.g. emeleusite family
e.g. zektzerite family

The presence of vacant sites in zektzerite ${ }^{6}$ that are potentially available for cation occupancy suggests that chemically complex substitutions may occur: for example in the present study a group of $\mathrm{LiNa}_{2} \mathrm{MSi}_{8} \mathrm{O}_{16}$ compounds which are apparently isostructural with emeleusite and zektzerite have been synthesized and characterized. 
This melting behaviour, corelate in someway with the chemistry of the substituent $\mathrm{M}^{3+}$ or $\mathrm{M}^{4+}$ ion. It has been observed that there is a regular decline in the congruent melting temperature as the function of size of the $\mathrm{M}^{\mathrm{s}_{+}}$ion. In this family of silicates the most stable phases are obtained when the size of the $\mathbf{M}^{3+}$ ion is about $0.8^{\circ} \mathrm{A}$. However, the formation of a stable phase is clearly not a function of ionic size alone: there are many other factors contributing towards it. For example, chromium, with its strong preference for octahedral sites, tends to stabilize the 6-tetrahedra repeat double-chain structure whereas $\mathrm{Al}$ and $\mathrm{Ga}$, which frequently appear in tetrahedral as well as octahedral coordination, do not stabilize these phases at atmospheric pressure. Thus, arguments based on site preference as well as ionic size are necessary to explain the compound formation and thermal stability of these structures.

This family of double-chain silicates exhibits a remarkable capacity to accommodate $\mathrm{M}^{3+}$ ions of varying size. When compared to other chain structures this tolerance is rather unusual. In general, silicate chain units of a given configuration are not very flexible. Thus, a change in the size of cation alters the chain periodicity or results in a change of anion type. This unusual tolerance of cations of varying size may be explained on the basis of a flexible octahedraltetrahedral chain present in the structure.

$\mathrm{M}^{3+} / \mathrm{M}^{4+}$ ions are octahedrally coordinated sharing oxygens with the silicate chain. These octahedra alternate with $\mathrm{LiO}_{4}$ tetrahedra forming a second type of chain which exhibits regular alternation of tetrahedra and octahedra. It lies parallel to and is linked with the double silicate chain. The introduction of progressively larger cations expands $\mathrm{MO}_{6}$ octahedra, but much of the expansion is taken up by compression or distortion of $\mathrm{LiO}_{4}$ tetrahedra. Thus, it is apparent that this flexibility of the tetrahedral-octahedral cation chain helps to maintain the basic structure.

Table 3 shows the data ${ }^{2,5,6}$ for the shape of the $\mathrm{MO}_{1}$ tetrahedra of emeleusite, zektzerite and synthetic $\mathrm{Na}_{2} \mathrm{Mg}_{2} \mathrm{Si}_{6} \mathrm{O}_{15}$. In' all these cases, the $\mathrm{MO}_{6}$ octahedra are found to be regular, whereas the $\mathrm{MO}_{4}$ tetrahedra are strongly distorted. These values indicate that, as the size of octahedrally coordinated ion increases, the $\mathrm{LiO}_{4}$ tetrahedra tend to approach a regular shape. Although this has to be confirmed by complete structure analysis of the relevant phases, enhanced thermal stability observed for phases containing somewhat larger $\mathrm{M}^{3+} / \mathrm{M}^{4+}$ cations strongly supports this argument.

As such, it seems possible that many more 6-tetrahedra repeat double-chain silicates can be synthesized if proper conditions for reaction can be experimentally determined. Similarly, many more such phases remain to be discovered in nature as naturally occurring minerals. 
Table 3: Bond lengths and angles in tetrahedral MO, groups

\begin{tabular}{lccc}
\hline & $\begin{array}{c}\mathrm{LiNa}_{2} \mathrm{FeSi}_{8} \mathrm{O}_{15} \\
\mathrm{M}=\mathrm{Li}\end{array}$ & $\begin{array}{c}\mathrm{LiNaZrSi}_{6} \mathrm{O}_{15} \\
\mathrm{M}=\mathrm{Li}\end{array}$ & $\begin{array}{c}\mathrm{Mg}_{2} \mathrm{Na}_{2} \mathrm{Si}_{6} \mathrm{O}_{15} \\
\mathrm{M}=\mathrm{Mg}\end{array}$ \\
\hline M-O distance $\left({ }^{\circ} \mathrm{A}\right)$ & $1.98-2.00$ & $1.95-1.96$ & $1.94-1.99$ \\
O-M-O angles $\left({ }^{\circ}\right)$ & 85.3 & 88.9 & 90.0 \\
& 110.3 & 107.5 & 108.9 \\
& 112.3 & 111.5 & 110.8 \\
& 136.0 & 113.3 & 131.4 \\
\hline
\end{tabular}

\section{Acknowledgement}

A part of the experimental work was carried out at the Department of Chemistry, University of Aberdeen, U.K. with financial assistance from the British Council.

\section{References}

1. Shahid K.A. \& Glasser F.P. (1972). Phase equilibria in the system $\mathrm{Na}_{2} \mathrm{O}$ $\mathrm{MgO}-\mathrm{SiO}_{2}$. Physics and Chemistry of Glasses 13: 27-32.

2. Cradwick M.E. \& Taylor H.F.W. (1972). Crystal structure of $\mathrm{Na}_{2} \mathrm{Mg}_{2} \mathrm{Si}_{6} \mathrm{O}_{15}$. Acta Crystallographica B28: 3583-3587.

3. Liebau F. (1985). Structural Chemistry of Silicates, pp. 87-99. SpringerVerlag, Heidelberg, FRG.

4. Dunn F.J., Rouse R.C., Cannon B. \& Nelen J.A. (1977). Synthesis and structure of $\mathrm{Na}_{2} \mathrm{LiFeSi}_{6} \mathrm{O}_{18}$. American Mineralogist 62: 416-417.

5. Ghouse S., Wan E., Dunn F.J. \& Rouse R.C. (1978). A new zirconium mineral, Zektzerite. American Mineralogist 63: 304-307.

6. Upton B.G.J., Hill P.G., Johnson O. \& Petersen O.V. (1978). Studies on mineral Emeleusite. Mineralogical Magazine 42: 31-35. 